\title{
Comparative Laying Performance, Egg Quality, Fertility and Hatchability of Guinea Fowl with Tilili, Horro and Potchefstroom Koekoek Chicken Breeds
}

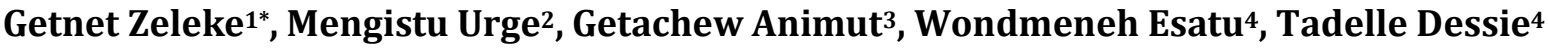 \\ ${ }^{1}$ Amhara Agricultural Research Institute, Bahir Dar, Ethiopia \\ ${ }^{2}$ School of Animal and Range Sciences, Haramaya University, Dire Dawa, Ethiopia \\ ${ }^{3}$ Ethiopian Agriculture Transformation Agency, Addis Ababa, Ethiopia \\ ${ }^{4}$ International Livestock Research Institute, Addis Ababa, Ethiopia \\ Email: `birukget2011@gmail.com
}

How to cite this paper: Getnet, Z., Mengistu, U., Getachew, A., Wondmeneh, E. and Tadelle, D. (2020) Comparative Laying Performance, Egg Quality, Fertility and Hatchability of Guinea Fowl with Tilili, Horro and Potchefstroom Koekoek Chicken Breeds. Open Journal of Animal Sciences, 10, 665-682. https://doi.org/10.4236/ojas.2020.104043

Received: July 29, 2020

Accepted: September 18, 2020

Published: September 21, 2020

Copyright $\odot 2020$ by author(s) and Scientific Research Publishing Inc. This work is licensed under the Creative Commons Attribution International License (CC BY 4.0).

http://creativecommons.org/licenses/by/4.0/

(c) (i) Open Access

\begin{abstract}
A study was conducted to compare laying performance, fertility, hatchability, and egg quality of guinea fowl (GF) with Horro (HR) and Tilili (TL) local chicken and Potchefstroom Koekoek (PK) exotic chicken. Forty five layers from each genotype and 6 cocks from each chicken genotype and 9 cocks from GF were used in 3 replications in a completely randomized design. Commercial layer feed was used ad libitum for the study that lasted 29 weeks. Daily DM intake per hen was 85, 114, 103 and $137 \mathrm{~g}(\mathrm{SEM}=3.1)$ for GF, HR, $\mathrm{TL}$ and PK, respectively, and was in the order of GF $<\mathrm{TL}<\mathrm{HR}<\mathrm{PK}$. Final body weight of hens was highest for PK (2490 g), intermediate for HR (1983 g) and lowest for TL $(1671 \mathrm{~g})$ and GF $(1641 \mathrm{~g})$. Egg number per production week followed a similar trend like that of DM intake and was 71, 101, 75 and 121 (SEM = 0.5) for GF, HR, TL and PK, respectively. Both fertility and hatchability of fertile eggs for GF were 57\%, which were lower than the mean of chicken genotypes by $41 \%$ and $34 \%$, respectively. Embryonic mortality was higher for GF (early, middle and late was $15.8 \%, 10.0 \%$. and $17.4 \%$ respectively) compared to chicken genotypes. Chick weight was highest for PK, intermediate for HR and TL and lowest for GF; while chick length was in the order of PK $>\mathrm{HR}>\mathrm{TL}>\mathrm{GF}$. Average egg weight was higher for PK eggs (46.4 g), intermediate for HR (43.5 g) and TL (42.3 g), and lowest for GF $(35.9 \mathrm{~g})$. Eggshell weight and thickness were higher for GF than chicken genotypes. Haugh unit was similar among genotypes. Such differences among poultry genotypes could be reflection of previous selection and breeding interventions, which are apparently more in chicken genotypes than GF. A
\end{abstract}


possible more stressful condition of the confined environment for GF versus chicken genotypes could have also contributed to such differences. This study highlighted the need of implementing future selection and breeding schemes to improve the performance of GF and TL birds to the level achieved by other genotypes.

\section{Keywords}

Guinea Fowl, Chicken, Egg Number, Fertility, Hatchability, Embryonic Mortality, Egg Weight

\section{Introduction}

Poultry production in Ethiopia plays a crucial role in generating employment opportunities, poverty reduction, improving family nutrition, and in women empowerment [1] [2]. It is a suitable business for resource-poor households due to the small land requirement and low initial investment costs needed. According to Central Statistics Agency of Ethiopia (CSA) [3], the poultry population of Ethiopia was estimated to be 56.1 million, of which $88.19 \%$ are indigenous birds, $6.45 \%$ are pure exotic and $5.36 \%$ are hybrids. Poultry meat and egg consumption in Ethiopia is low. For instance, the per capita consumption of eggs is around 4.1 eggs [1], which is far lower than the global and African average. To alter this scenario and to boost the production and consumption of poultry products, the Government of Ethiopia through the Livestock Master Plan of Ethiopia [4] has set ambitious targets. To achieve this envisioned goal, the introduction of commercial poultry species and the use of indigenous genotypes of better genetic potential were suggested. Moreover, poultry species like guinea fowl (Numidia meleagris) can also be used to contribute to the stretched poultry meat and egg production plan of the country.

Poultry includes all domestic birds such as chickens, turkeys, ducks, geese, ostrich, guinea fowl, doves and pigeons kept for food production (meat and eggs). In Ethiopia, however, the term poultry is almost synonymous with chicken, as the use of other poultry species is generally uncommon. Consequently, previous research and development endeavour in Ethiopia focused on chicken, while other poultry species like guinea fowl have been neglected. Despite their role as the source of egg and meat in some parts of Ethiopia, it even appeared that the existence of guinea fowl as a domesticated poultry species in the country has not been reported. It is currently realized that domestic guinea fowl exists as part of family poultry system in the Amhara Regional State of Etiopia, in Metema and Quara districts. The smallholder farmers in these districts are using the birds for home consumption and to generate income upon sale of the live birds and eggs. Apparently, there is a lack of information on the laying performance, fertility, hatchability and egg quality parameters of guinea fowl per se or as compared to chicken genotypes in the country. Such information is vital to recognize the po- 
tential of the resource base, for efficient utilization of the genetic resource, and to set strategies to improve the genetic potential and productivity of guinea fowl for future use in the country as an alternate poultry species. Therefore, this study was conducted to make a comparative assessment on egg-laying performance, reproduction performance, and egg quality parameters of guinea fowl and selected chicken genotypes kept under an intensive management system.

\section{Materials and Methods}

\subsection{Study Area, Animal Management and Experimental Design}

The experiment was conducted at Andassa Livestock Research Center (ALRC) of Amhara Agricultural Research Institute (ARARI), Ethiopia from February to September 2019. The centre is located at $11^{\circ} 29^{\prime} \mathrm{N}$ latitude and $37^{\circ} 29^{\prime}$ East longitude with an elevation of 1730 meters above sea level. It receives an average annual rainfall of $1150 \mathrm{~mm}$ with a temperature ranging from $6.5^{\circ} \mathrm{C}$ to $30^{\circ} \mathrm{C}$ [5].

Forty-five layer hens from each of guinea fowl (GF), Horro (HR; local chicken ecotypes obtained from the $11^{\text {th }}$ generation), Tilili (TL; local chicken ecotypes) and Potchefstroom Koekoek (PK; exotic dual chickens) with 9 cocks from GF and 6 cocks from each chicken genotypes were used for the study. Treatments were the four poultry genotypes in a completely randomized design (CRD). Each treatment was replicated thrice, comprising of 15 pullets and 2 cocks per replicate for chickens and 15 pullets and 3 cocks per replicate for guinea fowl. Three pens $(3.5 \mathrm{~m} \times 3.5 \mathrm{~m})$ were prepared for guinea fowls and covered with $0.5 \times 0.5$ $\mathrm{cm}$ wire mesh to prevent birds from flying out. Nine pens $(2.5 \mathrm{~m} \times 2.5 \mathrm{~m})$ were made and used for chicken genotypes.

The watering and feeding troughs and laying nests were thoroughly cleaned, disinfected and sprayed against external parasites before the commencement of the experiment. The floor of each pen was bedded with disinfected grass hay and was replaced when deemed appropriate. All birds (i.e., chicken and guinea fowl) used for this experiment were hatched on the same day. Birds were fed the same commercial starter (up to week 8), grower (week 9 to week 18) and layer rations thereafter for 29 weeks (Table 1). Pullets were vaccinated against Newcastle,

Table 1. Nutrient composition of the diet fed to experimental birds.

\begin{tabular}{cccc}
\hline Nutrients & Starter & Grower & Layer \\
\hline Metabolizable energy (ME-Kcal/kg) & 3000.0 & 2950.0 & 2800.0 \\
Crude protein (\% DM) & 20.5 & 18.8 & 16.0 \\
Crude fiber (\% DM) & 5.5 & 5.8 & 7.0 \\
Calcium (\% DM) & 0.9 & 0.9 & 3.55 \\
Fat (\% DM) & 6.5 & 5.0 & 5.0 \\
Moisture (\%) & 10.0 & 10.0 & 10.0 \\
\hline
\end{tabular}

The composition is as provided by the manufacturer (Alema Koudjis Feed PLC, Debre Zeit, Ethiopia,); DM = Dry matter. 
Gumburo (Infectious Bursal Disease-IBD) and Fowl Typhoid diseases using appropriate vaccine according to the manufacturer's recommendation. All layers during the 29 weeks of the laying performance study period were subjected to similar management, and received a total of 16 hours of light daily (i.e., 12 hours of day light and 4 hours of electric light), flourecent lamps of 36 watt were used to deliver about 30 lux of light intensity at the feeder trough level in experimental house. The laying period of 29 weeks for comparison was chosen due to the short laying phase of GF genotypes. Mortality was registered as it occurred and general health status was monitored throughout the experiment. Vitamins were given as supplement through drinking water. Each pen was equipped with laying nests bedded with teff straw.

\subsection{Feed Intake and Laying Performance of Hens}

Commercial layer feed was offered ad libitum twice per day at 0800 and 1700 hours and clean tap water were available all the time. The amount of feed offered and refused per pen was recorded daily, and the amount consumed was determined as the difference between the two. Hens were individually weighed by using sensitive electronic balance at the start and end of the experiment and body weight change was calculated as the difference between the two weights. Eggs laid in a pen were collected three times a day at 0800, 1300 and 1700 hours. Eggs collected daily were weighed immediately after collection from each pen and average egg weight was computed by dividing the total egg weight to the number of eggs. Egg mass per hen was calculated as total egg weight divided by the number of hens. Feed conversion ratio (FCR) was calculated as a gram of eggs produced per gram of feed consumed. Hen-day egg production was determined according to Hunton [6] as follows:

$$
\text { Hen-day egg production }(\%)=\frac{\text { Number of eggs collected per day }}{\text { Number of hens present that day }} \times 100
$$

\subsection{Egg Quality Characteristics}

Egg quality parameters, such as eggshell weight, eggshell thickness, albumen weight, albumen height, egg yolk weight, and egg yolk colour were determined at an interval of 30 days on freshly laid 6 eggs per replicate after breaking and separating each of the components. Eggs were broken on a flat mirror and the egg membrane was carefully removed from the shell. Eggshell, albumen and yolk weights were measured using sensitive balance. A precision micrometre was used to the nearest $0.01 \mathrm{~mm}$ for measuring eggshell thickness. Measures were taken at the three regions (large end, small end and on the equator region of the eggshell) and the means were taken. Yolk height was measured with a tripod micrometre. Yolk colour was determined by Egg Multitester Machine (EMT-5200, Robotics Technology, Tokyo, Japan), which was also used to measure albumen height and calculate the Haugh unit. Egg shape index $(S I)$ was calculated from egg width $(W)$ and egg length $(L)$, and yolk index $(Y I)$ was computed from yolk 
height $(Y H)$ and yolk width $(Y W)$ according to the below formula [7]:

$$
\begin{aligned}
& S I=\frac{W}{L} \times 100 \\
& Y I=\frac{Y H}{Y W} \times 100
\end{aligned}
$$

\subsection{Fertility, Hatchability and Embryonic Mortality}

Eggs for hatching were collected at the mid of the study period and stored for 7 days at $10^{\circ} \mathrm{C}-14^{\circ} \mathrm{C}$. Thirty eggs per pen with good shape, clean shell, no cracks, medium or average-sized were selected for incubation. Eggs from GF were set 7 days ahead of chicken eggs since the incubation period for GF is 28 days. Eggs were incubated with their sharp ends pointing downwards at $37.5^{\circ} \mathrm{C}-37.8^{\circ} \mathrm{C}$ and $60 \%$ relative humidity in the mini hatchery of 840 eggs capacity. The eggs were candled on the $9^{\text {th }}$ day of incubation for fertility determination. Percent fertility and hatchability were determined by the following formula:

$$
\text { Fertility }(\%)=\frac{\text { Number of eggs sett }- \text { Number of clear eggs }}{\text { Total number of eggs set }} \times 100
$$

Hatchability on fertile eggs basis $(\%)=\frac{\text { Number of chickes and keets hatched }}{\text { Number of fertile eggs set }} \times 100(5)$

Early, mid, late and pipe embryonic mortalities were determined from the incubated eggs by breaking all unhatched eggs using the method of Bonnier and Kasper [8]. Chick length was determined according to the method of Meijerhof [9]. Chick weight at hatching was determined by weighing the chick after 12 hours of hatching [10]. Yield percentage evaluates the weight loss during incubation and was calculated as the percentage of average chick weight to the average initial weight of egg set [10].

\subsection{Statistical Analysis}

Data were analyzed using the general linear model procedure of Statistical Analysis Systems Software [11]. Differences between treatment means were separated using Tukey Kuramer Test. The model used for data analysis was $Y_{i j}=\mu+G_{i}+$ $e_{i j}$ where: $Y_{i j}=$ represents the $j$ observation in the $i^{\text {th }}$ breed level; $\mu=$ overall mean; $G_{i}=$ genotype effect; and $e_{i j}=$ random error. The effect was considered significant at $\mathrm{P}<0.05$.

\section{Results}

\subsection{Feed Intake and Laying Performance of Hens}

Intake of DM and egg number/hen per production week was in the order of $\mathrm{PK}>\mathrm{HR}>\mathrm{TL}>\mathrm{GF}(\mathrm{P}<0.05$; Table 2). Initial and final body weights (BW), BW change, daily BW gain, and egg mass was highest for PK, intermediate for $\mathrm{HR}$ and lowest for the other two genotypes $(\mathrm{P}<0.05)$. Hen-day egg production 
Table 2. Dry matter intake, body weight change and egg-laying performance of different poultry genotype hens kept under an intensive management system.

\begin{tabular}{ccccccc}
\hline & \multicolumn{5}{c}{ Genotypes } \\
\cline { 2 - 7 } Parameters & GF & HR & TL & PK & SEM & P-values \\
\hline DM intake (g/hen/d) & $85^{\mathrm{d}}$ & $114^{\mathrm{b}}$ & $103^{\mathrm{c}}$ & $137^{\mathrm{a}}$ & 3.1 & 0.0001 \\
Initial body weight (g) & $1238^{\mathrm{c}}$ & $1301^{\mathrm{b}}$ & $1279^{\mathrm{c}}$ & $1693^{\mathrm{a}}$ & 14.6 & 0.0001 \\
Final body weight (g) & $1641^{\mathrm{c}}$ & $1983^{\mathrm{b}}$ & $1671^{\mathrm{c}}$ & $2490^{\mathrm{a}}$ & 35.3 & 0.0001 \\
Body weight change (g/hen) & $404^{\mathrm{c}}$ & $682^{\mathrm{b}}$ & $392^{\mathrm{c}}$ & $798^{\mathrm{a}}$ & 33.5 & 0.0001 \\
Body weight gain (g/hen/d) & $1.92^{\mathrm{c}}$ & $3.24^{\mathrm{b}}$ & $1.86^{\mathrm{c}}$ & $3.79^{\mathrm{a}}$ & 0.150 & 0.0001 \\
Point of lay (weeks) & $23.3^{\mathrm{a}}$ & $19.0^{\mathrm{c}}$ & $19.0^{\mathrm{c}}$ & $21.0^{\mathrm{b}}$ & 0.16 & 0.0001 \\
Peak production age (weeks) & $30.0^{\mathrm{a}}$ & $24.0^{\mathrm{b}}$ & $22.3^{\mathrm{b}}$ & $31.3^{\mathrm{a}}$ & 0.62 & 0.0001 \\
Hen-day egg production (\%) & $53.8^{\mathrm{bc}}$ & $54.9^{\mathrm{b}}$ & $47.1^{\mathrm{c}}$ & $66.9^{\mathrm{a}}$ & 2.33 & 0.0022 \\
Egg mass (g/hen/day) & $18.9^{\mathrm{c}}$ & $23.6^{\mathrm{b}}$ & $19.7^{\mathrm{c}}$ & $31.1^{\mathrm{a}}$ & 1.04 & 0.0001 \\
Total egg number/hen & $71^{\mathrm{d}}$ & $101^{\mathrm{b}}$ & $75^{\mathrm{c}}$ & $121^{\mathrm{a}}$ & 0.5 & 0.0001 \\
FCR (g feed DM/g egg) & $2.43^{\mathrm{b}}$ & $2.64^{\mathrm{b}}$ & $2.47^{\mathrm{b}}$ & $2.94^{\mathrm{a}}$ & 0.070 & 0.0040 \\
Mortality rate (\%) & $6.7^{\mathrm{b}}$ & $8.9^{\mathrm{b}}$ & $22.2^{\mathrm{a}}$ & $11.1^{\mathrm{b}}$ & 2.71 & 0.0150 \\
\hline
\end{tabular}

${ }^{\mathrm{a}, \mathrm{b}, \mathrm{c}}$ Means within a row with different superscripts $\operatorname{differ}(\mathrm{P}<0.05)$; GF = Guinea fowl; HR = Horro local chicken; TL = Tilili local chicken; $\mathrm{PK}=$ Potchefstroom Koekoek; SEM = Standard error of the mean; DM = Dry matter; ${ }^{\star}$ Egg production is the total number of eggs/hen during 29 weeks of experimental period.

was in the order of $\mathrm{PK}>\mathrm{HR}>\mathrm{TL}$, while the value for GF was similar $(\mathrm{P}>0.05)$ with those of HR and TL. Hens of GF started laying at a later age than chicken genotypes $(\mathrm{P}<0.05)$. Among the chicken genotypes point of lay was higher for $\mathrm{PK}$ than TL and HR that had similar values. The feed conversion ratio was higher for PK compared with the other genotypes that had similar values. The higher mortality rate was noted for TL $(\mathrm{P}<0.05)$ than the rest of genotypes, while values for the three genotypes were similar.

\subsection{Fertility, Hatchability and Embryonic Mortality}

Percent fertility and hatchability were higher $(\mathrm{P}<0.05)$ for chicken genotypes as compared to GF (Table 3). Early, pipe and late embryonic mortality were higher $(\mathrm{P}<0.05)$ for $\mathrm{GF}$ as compared to chicken genotypes, while values for chicken genotypes were similar. Mid embryonic mortality was similar $(\mathrm{P}>0.05)$ among poultry genotypes. Weight of day-old chick was highest for PK, intermediate for HR and TL, and lowest for GF keets $(\mathrm{P}<0.05)$. Chick yield percentage was unaffected by poultry genotypes $(\mathrm{P}>0.05)$. Chick length vary significantly $(\mathrm{P}<$ 0.01 ) and was in the order of $\mathrm{PK}>\mathrm{HR}>\mathrm{TL}>\mathrm{GF}$.

\subsection{Egg Quality Characteristics}

Egg quality characteristics with the exception of egg shape index, albumen height, Haugh unit, and proportion, diameter, index and color of egg yolk differ $(\mathrm{P}<0.05)$ among poultry genotypes (Table 4$)$. Egg length, egg width and egg 
Table 3. Fertility, hatchability, embryonic mortality and chick quality characteristics of different poultry genotype hens kept under an intensive management system.

\begin{tabular}{|c|c|c|c|c|c|c|}
\hline \multirow{2}{*}{ Parameters } & \multicolumn{4}{|c|}{ Genotypes } & \multirow{2}{*}{ SEM } & \multirow{2}{*}{ P-values } \\
\hline & GF & HR & $\mathrm{TL}$ & $\mathrm{PK}$ & & \\
\hline Average egg weight during incubation (g) & $35.4^{\mathrm{c}}$ & $43.0^{\mathrm{b}}$ & $43.9^{\mathrm{b}}$ & $46.5^{\mathrm{a}}$ & 0.43 & $<0.0001$ \\
\hline Fertility (\%) & $56.7^{\mathrm{b}}$ & $95.6^{\mathrm{a}}$ & $98.9^{\mathrm{a}}$ & $92.2^{\mathrm{a}}$ & 3.09 & 0.0001 \\
\hline Hatchability on fertile egg bases (\%) & $56.9^{\mathrm{b}}$ & $81.0^{\mathrm{a}}$ & $88.9^{\mathrm{a}}$ & $86.7^{\mathrm{a}}$ & 5.69 & 0.0144 \\
\hline Early embryonic mortality (\%) & $15.8^{\mathrm{a}}$ & $4.7^{\mathrm{b}}$ & $4.5^{\mathrm{b}}$ & $4.8^{\mathrm{b}}$ & 1.44 & 0.0013 \\
\hline Middle embryonic mortality (\%) & 10.0 & 4.7 & 4.5 & 6.0 & 1.81 & 0.1941 \\
\hline Late embryonic mortality (\%) & $17.4^{\mathrm{a}}$ & $8.2^{\mathrm{b}}$ & $6.7^{\mathrm{b}}$ & $5.9^{\mathrm{b}}$ & 2.15 & 0.0181 \\
\hline Pipe embryonic mortality (\%) & $17.4^{\mathrm{a}}$ & $7.0^{\mathrm{b}}$ & $6.8^{\mathrm{b}}$ & $4.8^{\mathrm{b}}$ & 2.11 & 0.0112 \\
\hline Chick weight (g) & $21.9^{c}$ & $29.2^{\mathrm{b}}$ & $28.9^{\mathrm{b}}$ & $32.8^{\mathrm{a}}$ & 0.71 & $<0.0001$ \\
\hline Yield percentage & 63.7 & 67.7 & 68.9 & 70.6 & 1.73 & 0.1072 \\
\hline Chick length $(\mathrm{cm})$ & $12.2^{\mathrm{d}}$ & $14.0^{\mathrm{b}}$ & $13.0^{c}$ & $14.6^{\mathrm{a}}$ & 0.17 & $<0.0001$ \\
\hline
\end{tabular}

${ }_{a, b, c}$ Means within a row with different superscripts differ $(\mathrm{p}<0.01)$; GF = Guinea fowl; HR = Horro localc chicken; TL = Tilili local chicken; PK = Potchfstroom Koekoek; SEM = Standard error of the mean.

Table 4. Egg quality parameters of different poultry genotype hens kept under an intensive management system.

\begin{tabular}{|c|c|c|c|c|c|c|}
\hline \multirow{2}{*}{ Egg quality parameters } & \multicolumn{4}{|c|}{ Genotypes } & \multirow{2}{*}{ SEM } & \multirow{2}{*}{ P-values } \\
\hline & GF & HR & $\mathrm{TL}$ & PK & & \\
\hline Average fresh egg weight (g) & $35.9^{c}$ & $43.5^{\mathrm{b}}$ & $42.3^{\mathrm{b}}$ & $46.4^{\mathrm{a}}$ & 0.55 & $<0.0001$ \\
\hline Egg length (mm) & $47.0^{\mathrm{b}}$ & $50.2^{\mathrm{a}}$ & $51.3^{\mathrm{a}}$ & $51.5^{\mathrm{a}}$ & 0.59 & 0.0022 \\
\hline Egg width (mm) & $36.1^{\mathrm{b}}$ & $38.2^{\mathrm{a}}$ & $38.6^{\mathrm{a}}$ & $39.5^{\mathrm{a}}$ & 0.39 & 0.0019 \\
\hline Egg shape index & 76.8 & 76.0 & 75.3 & 76.7 & 1.01 & 0.7362 \\
\hline Egg shell weight (g) & $6.57^{\mathrm{a}}$ & $5.55^{\mathrm{b}}$ & $5.47^{\mathrm{b}}$ & $5.85^{\mathrm{b}}$ & 0.190 & 0.0159 \\
\hline Egg shell proportion (\%) & $18.3^{\mathrm{a}}$ & $12.8^{\mathrm{b}}$ & $12.9^{\mathrm{b}}$ & $12.6^{\mathrm{b}}$ & 0.71 & 0.0021 \\
\hline Egg shell thickness (mm) & $0.73^{\mathrm{a}}$ & $0.37^{\mathrm{b}}$ & $0.36^{\mathrm{b}}$ & $0.42^{\mathrm{b}}$ & 0.050 & 0.0062 \\
\hline Albumen weight (g) & $18.5^{\mathrm{c}}$ & $24.5^{\mathrm{b}}$ & $24.2^{\mathrm{b}}$ & $27.4^{\mathrm{a}}$ & 0.40 & $<0.0001$ \\
\hline Albumen proportion (\%) & $51.5^{\mathrm{c}}$ & $56.4^{\mathrm{b}}$ & $57.2^{\mathrm{b}}$ & $59.1^{\mathrm{a}}$ & 0.38 & $<0.0001$ \\
\hline Albumen height (mm) & 4.78 & 5.30 & 4.84 & 4.92 & 0.140 & 0.1293 \\
\hline Haugh unit & 77.2 & 77.9 & 76.1 & 74.3 & 0.95 & 0.1106 \\
\hline Egg yolk weight (g) & $11.0^{\mathrm{b}}$ & $13.4^{\mathrm{a}}$ & $12.7^{\mathrm{a}}$ & $13.2^{\mathrm{a}}$ & 0.33 & 0.0042 \\
\hline Egg yolk proportion (\%) & 30.6 & 30.9 & 29.8 & 28.9 & 0.64 & 0.0929 \\
\hline Egg yolk height (mm) & $13.4^{\mathrm{b}}$ & $14.8^{\mathrm{a}}$ & $13.8^{\mathrm{b}}$ & $15.3^{\mathrm{a}}$ & 0.20 & 0.0007 \\
\hline Egg yolk diameter (mm) & 42.2 & 34.1 & 32.6 & 33.5 & 0.46 & 0.0753 \\
\hline Egg yolk index & 41.48 & 43.33 & 42.48 & 45.66 & 1.09 & 0.1211 \\
\hline Yolk color (EMT-5200) & 4.66 & 4.58 & 4.62 & 4.65 & 0.130 & 0.9695 \\
\hline Yolk:Albumen ratio & $0.59^{\mathrm{a}}$ & $0.55^{\mathrm{b}}$ & $0.52^{\mathrm{bc}}$ & $0.48^{\mathrm{c}}$ & 0.010 & 0.0023 \\
\hline
\end{tabular}

a,b,c Means within a row with different superscripts differ $(\mathrm{p}<0.01)$; GF = Guinea fowl; HR = Horro local chicken; TL $=$ Tilili local chicken; PK = Potchfstroom Koekoek; SEM = Standard error of the mean; EMT-5200 = Egg Multi Tester, Robotics Technology Co.Ltd., Tokyo, Japan. 
yolk weight was lower $(\mathrm{P}<0.05)$ for GF as compared to chicken genotypes. Conversely, the weight, thickness and proportion of eggshell was higher $(\mathrm{P}<$ $0.05)$ for GF as compared to chicken genotypes. Albumen weight and albumen proportion was highest for $\mathrm{PK}$, intermediate for HR and TL and lowest for GF $(\mathrm{P}<0.05)$. Egg yolk height was higher for $\mathrm{PK}$ and $\mathrm{HR}$ as compared to the other two genotypes. The yolk to albumen ratio was higher $(\mathrm{P}<0.01)$ for $\mathrm{GF}$ as compared to chicken genotypes. Among the chicken genotypes, yolk to albumen ratio was higher for HR than PK.

\section{Discussion}

\subsection{Feed Intake and Performance of Hens}

This study evaluated feed intake and performance of GF and local and exotic chicken genotypes kept under an intensive management system. In the current study, DM intake was the highest for PK followed by HR and then by TL, while the value for GF was the lowest. Differences in DM intake among genotypes appeared to be consistent with variation in BW and egg production of genotypes, which is apparently a consequence of variation in genetic potential partly due to differences in past genetic improvement interventions. Halima [5] noted higher daily DM intake of $183 \mathrm{~g} /$ hen and FCR of 10.5 , and lower mature hen BW of $1444 \mathrm{~g}$ at 44 weeks of age for TL hens compared to the results of the current study. Daily DM intake of $128 \mathrm{~g} /$ hen and average BW of 1737 and $1813 \mathrm{~g} / \mathrm{bird}$ at 40 and 60 weeks of age, respectively was reported for PK hens [12], which were lower than values of the present study. Etalem et al. [13] reported for HR improved local chickens fed on diet containing $2950 \mathrm{Kcal}$ ME and CP $21 \%$ daily DMI, and FBW to be $118.18 \mathrm{~g}$, and $1497.9 \mathrm{~g}$ at $24-34$ weeks of age, which was moderately similar in DMI and lower in FBW as compared to the current findings. For GF, a study in Nigeria [14] reported DM intake, final BW, and average daily gain of $101 \mathrm{~g} / \mathrm{hen}, 1423 \mathrm{~g}$ and $2.09 \mathrm{~g}$, respectively, close to the results of the current study. Variations in DM intake and mature BW of birds among studies might be attributed to differences in feed quality, management practices, and environmental conditions during the experimental periods.

In the present study, hens of GF started laying eggs at 163 days of age, 16 days later than PK and 30 days later than HR and TL hens. Previous reports noted that point of lay for HR hens obtained from 6 to 7 generations was 153 days [15], and for TL hens was 157 days [5], which was higher than the current result. For PK hens, point of lay of 140 days was reported [12], although a lower value of 130 days was noted in South Africa [16], both of which were lower than the current result. The sexual maturity for GF hens reported in Western Africa was 24 weeks of age [17], a week behind the finding of this study. Fisseha et al. [18] reported that the average age of local pullets at first laying kept under scavenging system was 5.74 and 7.07 months for Bure and Dale districts of Ethiopia, respectively, values obviously much higher than the current study. According to Maoba [19], a hen normally starts egg production at around $20-21$ weeks of age and 
continues to lay for 52 weeks on average, which appears to be consistent with the current result. Sexual maturity of birds is apparently impacted by feed quality, daylight hours, management practices, and genotypes, which might be the reason for differences in point of lay observed among studies.

Peak egg production was attained 7, 15, 13 and 10 weeks after point of lay for GF, HR, TL and PK hens, respectively. The egg-laying period was 20 weeks long for GF hens, whereas chicken genotypes laid for 29 weeks in our experiment and even continued laying then after. Peak egg production for GF was short-lived and there was a sharp decline in egg production; whereas chicken genotypes maintained high egg production up to 48 weeks of age with a gradual decline in production. This presumably affected the overall egg number obtained from the different genotypes. Egg-laying period of 23 weeks long was noted for GF kept under intensive management system [20], a bit longer than the current study. Average egg production for GF from different studies ranged 55 - 100 eggs/hen per production period [20] [21] [22], and values of the present study are within this range. For TL hens higher number of egg/hen/year of 147, and lower egg mass of $17.4 \mathrm{~g}$ and HDEP of $40 \%$ compared to the current study was reported [5]. Similarly, for HR local chicken ecotypes, number of eggs/hen/year and percent egg production was reported as 171 and $49.1 \%$ respectively [15]. Dawud et al. [12] indicated for PK genotypes that the egg number and HDEP\% to be 149.9 and 48.7 respectively. The current result of lower egg performance parameters for GF and TL as compared to PK and HR might be in part due to differences in past breeding interventions undertaken for the genotypes. This suggests for greater future potential for selection and breed improvement activities in GF and TL genotypes, to use them as an alternative adapted poultry genotypes to the local environment.

\subsection{Fertility, Hatchability and Embryonic Mortality}

The fertility of GF eggs was about $41 \%$ lower than the mean value of the chicken genotypes, i.e., $95.6 \%$. For GF hens fertility values ranging $43 \%$ - 92\% were reported by different authors [23]-[29], and the current result is within the reported range. A slightly lower fertility rate of $90 \%$ compared to the current finding was reported for TL hens [5]. The low fertility of GF compared to chicken genotypes might be in part due to the fact that GF cocks have a smaller testicular size (1 - $9 \mathrm{~g})$ than chicken cocks (14 - $16 \mathrm{~g})$ [30] [31]. This may place GF at a disadvantage because sperm production is positively correlated with the size of the testis in poultry [32]. The low fertility of GF hens could be also attributed to the infrequent mating of GF males, since they were fighting each other for social hierarchy in the pen, this might also contribute to preferential mating of cocks to hens since mating was associated with monogamous sexual behaviour in guinea fowl [31]. Fertility performance of eggs depends on genotypic factors in addition to other factors [33]. Previous reports noted a fertility rate of $77 \%$ for HR [34] and $78 \%-82 \%$ for PK hens [35], which were lower than the current finding. 
Fertility may be affected by various factors, including genetic factors, the general condition of the parents, mating rate, age, egg-storage duration and condition, weather conditions, and geographical location [26] [33]. The similarity of high fertility observed among chicken genotypes in this study justifies the better reproductive capacity in chicken genotypes under confinement as compared to GF.

In the present study hatchability of fertile eggs was lower for GF (57\%) than chicken genotypes with a mean value of $86 \%$. The present result for GF was within the reported hatchability values that widely vary, ranging from $45 \%-88 \%$ [22] [36] [37] [38] [39] [40]. Hatchability of fertile eggs for TL [5] and HR [34] kept under intensive management was $54.3 \%$ and $62.6 \%$, respectively, lower than the current result. For PK hens hatchability of fertile eggs of $83 \%$ [34] and $91.4 \%$ [35] were reported, which were in agreement with the present result. Hatchability in poultry depends on numerous genetic and environmental factors such as breed differences, male to female ratio, nutrition of parents, egg quality and egg storage conditions [29] [33] [41]. Fertility and hatchability in poultry are interrelated heritable traits and varies among breeds and individuals within breeds [33]. The lower hatchability exhibited by GF eggs compared to eggs of chicken genotypes in the current study might be partly due to thicker eggshells and small-sized eggs of GF [26] [41].

The overall embryonic mortality in GF was higher than that observed for chicken genotypes in the current study. A range of $15 \%-20 \%$ overall embryonic mortality was noted for GF [42], which was in line with this study. Conversely, lower embryonic mortality values ranging $4.96 \%-5.70 \%$ [20], and early, middle and late-period embryonic mortalities of $1.65 \%, 2.15 \%$ and $5.71 \%$, respectively [27] was also reported for GF eggs. The embryonic mortality from Benin local chickens of Forest and Savanah ecotypes were $6.8 \%$ and 6.1\%, respectively [43], which was in line with our findings for chicken genotypes. On the other hand, a study on HR and PK genotypes under station condition yielded a higher mortality rate of $21.5 \%$ and $12.2 \%$, respectively [34]. The higher pipe embryonic mortality from GF compared to chicken genotypes might be related to the relatively harder eggshell thickness of eggs of GF.

In this study, the highest chick weight and chick length at hatching were recorded for PK and the lowest values were obtained for GF keets, while yield percentage was similar among genotypes. Previous reports noted an average keet weight at hatching of $25.0 \mathrm{~g}$ [27], chick weight at hatching for HR of $30.2 \mathrm{~g}$ and for PK of $40.0 \mathrm{~g}$ [34], where values except for PK was in agreement with this study. Regarding yield percentage, the poultry industry has set 66 - 68 percent chick yield as a target [44], suggesting that baby chicks in the present study generally to be categorized under normal range. A $51.4 \%$ chick yield from GF eggs was reported before [27], which is lower than the current finding. During incubation, egg weight decreased because of water loss from incubated eggs contributing to chick weight variation. Generally, differences observed in chick weight and length among poultry genotypes is a reflection of genetic diversity among 
species and breeds of poultry.

\subsection{Egg Quality Characteristics}

\subsubsection{External Egg Quality}

Egg weight, length and width in this study were higher for chicken genotypes than GF counterparts. Consistent with the current finding, a study in Nigeria reported higher egg weight for chicken versus GF. The present values on egg weight for GF were within the range of reported values of 32 - $42 \mathrm{~g}$ [36] [45] [46]. In agreement with the current result, egg weight for TL kept under intensive management was $41.7 \mathrm{~g}$ [5], while the $47.8 \mathrm{~g}$ egg weight noted for HR [47] was slightly higher than the present result. Dawud et al. [12] reported $53.0 \mathrm{~g}$ for PK egg weight, which was higher than the current value. For GF egg length ranging $42-52 \mathrm{~mm}$ and egg width ranging $35-38 \mathrm{~mm}$ was reported [14] [48] [49]; whereas egg length and width of HR was 52 and $39 \mathrm{~mm}$ [47] and for PK was 53 and $41 \mathrm{~mm}$ respectively, [12] [50], which were more or less in line with the current result. Several studies have reported strong and positive associations between egg weight, egg length and egg width [51] [52] [53]. Moreover, egg weight was affected by bodyweight of laying hens [54] and egg size is usually related to the body size of the laying hens [55] which appeared to be consistent with the observation of this study. Egg shape index of this study indicates the normal shape of eggs for all genotypes considered [49].

Eggshell is an important egg quality parameter considered in a breeding programme to reduce eggshell breakage. Eggs with low-quality shells contribute to economic losses in the production of eggs for consumption [56]. In this study, eggshell parameters were higher for GF versus chicken genotypes. Previous results on eggshell parameters vary widely. A range of values for eggshell weight of 5.8 - $6.5 \mathrm{~g}$ [14] [49] [57] and eggshell thickness of 0.30 - $0.79 \mathrm{~mm}$ [14] [20] [49] [58] was noted for GF, and the present results are within the range of reported values. The eggshell thickness of $0.36 \mathrm{~mm}$ for HR [47] and $0.35 \mathrm{~mm}$ for Ethiopian local chicken eggs were reported [59], which was in line with the results of HR and TL birds in the present study. Eggshell weight and eggshell thickness for PK eggs were $5.67-7.01 \mathrm{~g}$ and $0.29-0.34 \mathrm{~mm}$, respectively [34] [60] and values for shell weight were in agreement with the present result while shell thickness of the present result was higher. However, much higher eggshell thickness values of $0.69-0.71 \mathrm{~mm}$ were reported [5] for local Ethiopian chicken genotypes. The rate of eggshell deposition in GF uterus was similar to that of chicken hens, although the duration of shell deposition was greater by 2.1 hours for GF hens compared to chicken hens [61]. This presumably resulted in more calcium deposition in GF eggs leading to greater eggshell weight and thickness observed for GF eggs.

\subsubsection{Internal Egg Quality}

Albumen weight and proportion in the present study took the trend of egg weight and was lowset for GF and highest for PK. This is apparently due to the 
fact that albumen weight has been more closely associated with egg weight [62]. Previously reported values for albumen weight were $29.7 \mathrm{~g}$ for PK [34], $23.5 \mathrm{~g}$ for TL [5], and $22.9 \mathrm{~g}$ for GF [63], generally comparable to the results of this study. Internal egg quality traits are seemingly influenced by differences in genotype apart from the quality and quantity of the feed supplied to the birds [64] [65]. In the current study genotypic variations obviously might have led to differences observed in the measured albumen parameters. Albumen quality is described primarily by Haugh units (HU). According to USDA's egg grading manual [66], eggs are classed into AA, A and B grades. Grade AA is the highest quality with a $\mathrm{HU}$ value of above 72 . The $\mathrm{HU}$ in this study was above 72 for all genotypes, and hence eggs are all in the highest quality category of grade AA.

Egg yolk weight and height were higher for chicken eggs as compared to GF in this study, presumable a consequence of variation in the weight and size of eggs of the different genotypes. A range 12.4 - $13.5 \mathrm{~g}$ for yolk weight and $13.1-16.7$ $\mathrm{mm}$ for yolk height was reported for GF [20] [55] [63], in close agreement with the results of this study. In agreement with the present result, yolk weight of $13.34 \mathrm{~g}$ was reported for TL [5]. On the other hand, a relatively higher yolk height of $17.73 \mathrm{~mm}$ compared to the current result was noted for HR [47]. For PK hens, yolk weight of 14.5 - $16.3 \mathrm{~g}$ and yolk height of 17.6 - $17.8 \mathrm{~mm}$ was reported previously [34] [67], slightly higher than the current result. Egg yolk color was not affected by genotype in this study, possibly due to the feeding of the same ration for all birds. Yolk color in this study ranged 4.58 - 4.66, which was in a range of pale yellow yolk color. Yolk to albumen ratio was higher for GF versus chicken genotypes in the present study, which could be attributed to differences in the size and weight of eggs among the poultry genotypes. It has been noted that yolk to albumen ratio tends to be greater in smaller eggs than in larger eggs [68].

\section{Conclusion}

Generally, most of the main production parameters such as DM intake, total egg production, egg weight, chick weight and chick length were in the order of PK > HR $>$ TL $>$ GF. Moreover, fertility, hatchability and embryonic mortality were all lower for GF versus chicken genotypes. Such differences among genotypes could be a reflection of previous selection and breeding interventions. The PK breed of South Africa was developed by crossing Black Australope with White Leghorn [69]; the HR local chicken of Ethiopia was improved up to 11 generations through selective breeding schemes [15], and TL could have been improved through owning better-performing birds by farmers over the years. Utilization of GF birds being a more recent phenomenon in Ethiopia, efforts to select and own better-performing birds might have been limited if at all exists. The GF being more adapted to scavenging condition as compared to the chicken genotypes might have also impacted performance, as it appeared that GF birds were relatively more stressed to the confined environment than the chicken genotypes. In 
conclusion, this study highlighted the need for implementing future selection and breeding schemes to improve the performance of GF and TL birds to the level achieved by other genotypes.

\section{Limitation of the Study}

The study was focused on the laying and reproductive performances of GF and chicken genotypes at indoor production system, which has resulted in lower fertility rates from GF genotypes due to the nature of the birds which has adapted to seasonal laying ability and scavenging system, the entire laying capacity of chicken genotypes was not assessed, since the full laying period for chicken genotypes can extend to 52 weeks.

\section{Acknowledgements}

Authors express gratitude to African Chicken Genetic Gain (ACGG) Project for funding the research, Ethiopian Institute of Agricultural Research (EIAR) for facilitation the budget, and Amhara Agricultural Research Institute for covering part of the research cost. Andassa Livestock Research Center (ALRC) is duly acknowledged for availing research facilities, and poultry research case team of ALRC for assistance during the execution of the study.

\section{Conflicts of Interest}

The authors declare no conflicts of interest regarding the publication of this paper.

\section{References}

[1] United Nations Food and Agriculture Organization FAO (2019) Poultry Sector Ethiopia. FAO Animal Production and Health Livestock Country Reviews No. 11. Rome.

[2] Padhi, M.K. (2016) Importance of Indigenous Breeds of Chicken for Rural Economy and Their Improvements for Higher Production Performance. Scientifica, 2016, Article ID: 2604685. https://doi.org/10.1155/2016/2604685

[3] Central Statistical Agency (CSA) (2018) Federal Democratic Republic of Ethiopia, Central Statistical Agency, Agricultural Sample Survey, Livestock and Livestock Characteristics. Statistical Bulletin 587, Addis Ababa.

[4] Shapiro, B.I., Gebru, G., Desta, S., Negassa, A., Nigussie, K., Aboset, G. and Mechal, H. (2015) Ethiopia Livestock Master Plan. ILRI Project Report. International Livestock Research Institute (ILRI), Nairobi.

[5] Mogesse, H.H. (2007) Phenotypic and Genetic Characterization of Indigenous Chicken Populations in Northwest Ethiopia. PhD Thesis, University of Free State, Bloemfontein.

[6] Hunton, P. (1995) Egg Production, Processing and Marketing. In: World Poultry Science, Elsevier, Tokyo, 457-480.

[7] Panda, P.C. (1996) Shape and Texture. In: Textbook on Egg and Poultry Technology, 3rd Edition, Vikas Publishing House, New Delhi, 57.

[8] Bonnier, P. and Kasper, H. (1990) Hatching Eggs by Hens or in an Incubator. 
Agrodok No. 34. Agromisa, Wageningen, 39 p.

[9] Meijerhof, R. (2006) Chick Size Matters. World Poultry Science, 22, 30-31.

[10] Molenaar, R., Reijrink, I., Meijerhof, R. and Van Den Brand, H. (2009) Relationship between Hatchling Length and Weight on Later Productive Performance in Broilers. Hatch Tech B. V., Adaptation Physiology Group, Wageningen University, Wageningen.

[11] SAS (Statistical Software System) (2009) SAS User's Guide, Stastics. SAS Institute, Inc., Cary.

[12] Ibrahim, D., Goshu, G., Esatu, W., Bino, G. and Abebe, T. (2018) Comparative Study of Production and Reproductive Performance of Various Trains of Chicken Parent Layers Raised in Floor Pens. Ethiopian Journal of Agricultural Sciences, 28, 79-93.

[13] Tesfaye, E., Esatu, W., Melese, K. and Habte, T. (2019) Effect of Energy-Protein Optimization on the Growth and Production Performances of Local Chickens. Acta Scientific Nutritional Health, 3, 4-12.

[14] Onunkwo, D.N. and Okoro, I.C. (2015) Egg Production Performance of Three Varieties of Guinea Fowls in Humid Tropics. International Journal of Current Research and Review, 7, 1-6.

[15] Esatu, W. (2015) Genetic Improvement in the Indigenous Chicken of Ethiopia. PhD Thesis, Wageningen Institute of Animal Sciences, Wageningen.

[16] Grobbelaar, J.A.N., Sutherland, B. and Molalakgotla, N.M. (2010) Egg Production Potentials of Certain Indigenous Chicken Breeds from South Africa. Animal Genetic Resources, 46, 25-32. https://doi.org/10.1017/S2078633610000664

[17] Houndonougbo, P.V., Bindelle, J., Chrysostome, C.A.A.M., Hammami, H. and Gengler, N. (2017) Characteristics of Guinea Fowl Breeding in West Africa: A Review. Tropicultura, 35, 222-230.

[18] Moges, F., Tegegne, A. and Dessie, T. (2010) Indigenous Chicken Production and Marketing Systems in Ethiopia: Characteristics and Opportunities for Market-Oriented Development. IPMS (Improving Productivity and Market Success) of Ethiopian Farmers Project Working Paper 24. ILRI, Nairobi.

[19] Maoba, S. (2016) Production Performance and Profitability Analysis of Small Scale Layer Projects Supported through Casp in Germiston Region, Gauteng Province. South African Journal of Agricultural Extension, 44, 42-49. https://doi.org/10.17159/2413-3221/2016/v44n1a368

[20] Bernacki, Z., Kokoszynski, D. and Bawej, M. (2013) Laying Performance, Egg Quality and Hatching Results in Two Guinea Fowl Genotypes. European Poultry Science, 77, 109-115.

[21] Konlan, S.P., Avornyo, F.K., Karbo, N. and Sulleyman, A. (2011) Increasing Guinea Fowl Eggs Availability and Hatchability in the Dry Season. Journal of World s Poultry Research, 1, 1-3. http://jwpr.science-line.com

[22] Farrel, D. (2017) Guinea Fowl-Poultry Hub. http://www.poultryhub.org/species

[23] Ebegbulen, V.N., Bassey, A.O. and Bassey, O. (2017) Genotype Influence on Production, Fertility and Hatchability of Eggs of Guinea Fowl (Numida meleagris) in a Tropical Rain Forest Zone of Nigeria. Journal of Scientific and Engineering Research, 4, 94-97.

[24] Xuan, K.D.T.D., Szalay, I., Tien, P.D., Thu, P.T.M. and Phuong, T.N.L. (2015) Production Studies of a Guinea Fowl Variety of Hungarian Origin in the Tropical Regions of Vietnam. Athens Journal of Sciences, 2, 203-212. 
https://doi.org/10.30958/ajs.2-3-4

[25] Agbolosu, A.A., Teye, G.A., Jebuni, S.N., Ansah, T. and Naandam, J. (2012) Comparative Study of Growth and Laying Performance of Indigenous Layer Guinea Fowls (Numida meleagris) from Upper East, Upper West and Northern Regions of Ghana. Agriculture and Biology Journal of North America, 3, 354-359. https://doi.org/10.5251/abjna.2012.3.9.354.359

[26] Adu-Aboagye, G., Nyameasem, J.K., Ahiagbe, K.M.J., Ansah, K.O., Zagbede, G.A. and Agbe, K.K. (2020) Reproductive Traits of the Indigenous Guinea Fowl under Tropical Humid Conditions; the Effect of Egg Size. Livestock Research for Rural Development, 32, Article 55. http://www.lrrd.org/lrrd32/4/gadua32055

[27] Yamak, U.S., Boz, M.A. and Sarica, M. (2015) Changes in Guinea Fowl Fertility and Hatching Traits over a 4-Month Laying Season with Long-Term Egg Storage Conditions. Indian Journal of Animal Research, 49, 532-536.

http://www.arccjournals.com/www.ijaronline.in https://doi.org/10.5958/0976-0555.2015.00124.7

[28] Obike, O.M., Nwachukwu, E.N. and Ukewulonu, I.E. (2014) Effect of Strain and Associations of Some Fertility and Hatchability Traits of Indigenous Guinea Fowls Raised in the Rain-Forest Zone of South-East Nigeria. Global Science Research Journals, 2, 98-102. http://www.globalscienceresearchjournals.org

[29] Yamak, U.S., Sarica, M., Boz, M.A. and Ucar, A. (2016) The Effect of Eggshell Thickness on Hatching Traits of Partridges. Brazilian Journal of Poultry Science, 18, 49-53. https://doi.org/10.1590/1806-9061-2015-0039

[30] Nwagu, B.I. and Alawa, C.B.I. (1995) Guinea Fowl Production in Nigeria. World Poultry Science Journal, 51, 260-270. https://doi.org/10.1079/WPS19950018

[31] Belshaw, R.H. (1985) Guinea Fowl of the World. World of Ornithology. Minirod Book Services, Hampshire.

[32] Ayorinde, K.L., Ayeni, J.S.O. and Oluyemi, J.A. (1989) Laying Characteristics and Reproductive Performance of Four Indigenous Helmeted Guinea Fowl Varieties (Numidia Meleagris Galeata Pallas) in Nigeria. Tropical Agriculture (Trinidad), 66, 277-280.

[33] Islam, M.S., Howlider, M.A.R., Kabir, F. and Alam, J. (2002) Comparative Assessment of Fertility and Hatchability of Barred Plymouth Rock, White Leghorn, Rhode Island Red and White Rock Hen. International Journal of Poultry Science, 1, 85-90. https://doi.org/10.3923/ijps.2002.85.90

[34] Essatu, W., Ibrahim, D. and Melesse, A. (2011) Comparative Evaluation of Fertility and Hatchability of Horro, Fayoumi, Lohmann Silver and Pochefstroom Koekoek Breeds of Chicken. Asian Journal of Poultry Science, 5, 124-129.

https://doi.org/10.3923/ajpsaj.2011.124.129

[35] Yimer, D.I. (2019) Comparative Study of Production and Reproductive Performance of Parent Stock and Commercial Layer Chickens under Different Management Conditions in Ethiopia. PhD Thesis, College of Veterinary Medicine and Agriculture, Department of Animal Production Studies, Addis Ababa University, Bishoftu.

[36] Khairunnesa, M., Das, S.C. and Khatun, A. (2016) Hatching and Growth Performances of Guinea Fowl under Intensive Management System. Progressive Agriculture, 27, 70-77. https://doi.org/10.3329/pa.v27i1.27544

[37] Ancel, A., Armand, J. and Girard, H. (1994) Optimum Incubation Conditions of the Domestic Guinea Fowl Egg. British Poultry Science, 35, 227-240.

https://doi.org/10.1080/00071669408417687 
[38] Yamak, U.S., Boz, M.A., Ucar, A., Saica, M. and Onder, H. (2016) The Effect of Eggshell Thickness on the Hatchability of Guinea Fowl and Pheasants. Brazilian Journal of Poultry Science, 18, 13-16. https://doi.org/10.1590/1806-9061-2015-0214

[39] Naandam, J. and Issah, G.B. (2012) Hatchability of Guinea Fowls Eggs and Performance of Keets under the Traditional Extensive System in Tolon Kumbungu District of Ghana. Online Journal of Animal Feed Research, 2, 253-257.

[40] Ahaotu, E.O., Umoh, G., Onweagba, A.E., Chukwu, A.O. and Iwuanyanwu, U.P. (2013) Guinea Fowl Keets Performance under Improved and Extensive Conditions in Anthony Patience Farms, Atta-Ikeduru, Imo State, Nigeria. International Journal of Agriculture and Biosciences, 2, 82-86.

[41] Kozuszek, R., Kontecka, H., Nowaczewski, S. and Rosinski, A. (2009) Storage Time and Eggshell Colour of Pheasant Eggs vs the Number of Blastodermal Cells and Hatchability Results. Folia Biologica, 57, 121-130.

https://doi.org/10.3409/fb57_3-4.121-130

[42] Moreki, J.S. and Mothei, K.M. (2013) Effect of Egg Size on Hatchability of Guinea Fowl Keets. International Journal of Innovative Research in Science, Engineering and Technology, 2, 5480-5483.

[43] Youssao, A.K.I., Senou, M., Dahouda, M., Idrissou, N.D., Amoussou-Sydol, E., Tougan, U.P., Ahounou, S., Yapi-Gnaoré, V., Kayang, B., Rognon, X., Tixier-Boichard, M. and Kpodékon, M.T. (2013) Laying Performances and Egg Quality Characteristics of F1 Crossbred Hens Resulting from Label Rouge (T55XSA51) and Two Local Ecotypes as Parental Lines. Global Journal of Poultry Farming and Vaccination, 1, 93-102.

[44] Cobb-vantress.com (2013) Hatchery Management Guide.

[45] Ikani, E.I. and Dafwang, I.I. (2004) The Production of Guinea Fowl in Nigeria. $E_{X-}$ tension Bulletin, 207, 32 p. http://www.naerls.gov.ng/extmat/bulletins/Guineafowl.pdf

[46] Shaker, A.S., Akram, S.A., Ameen, Q.A., Mustafa, N.A., Kirkuki, S.M.S. and Mohammed, M.S. (2019) The Variation between the Proportions of Egg External and Internal Traits in Four Species of Birds. Proceedings of 170 th, the IRES International Conference, Rome, 20-21 August 2019.

[47] Hussen, K., Goshu, G., Esatu, W. and Abegaz, S. (2019) Comparing Egg Quality Traits of Crossbred Local Horro Ecotype with Dominant Red Bared D 922 Exotic Chickens: A Step towards Synthetic Breed Development in Ethiopia. British Journal of Poultry Sciences, 8, 1-9.

[48] Gwaza, D.S. and Elkanah, H. (2017) Assessment of External Egg Characteristics and Production Indices of the Dual Purpose French Guinea Fowl under Semiarid Conditions in Nigeria. Research and Reports on Genetics, 1, 13-17.

[49] Alkan, S., Karsli, T., Galiç, A. and Karabag, K. (2013) Determination of Phenotypic Correlations between Internal and External Quality Traits of Guinea Fowl Eggs. Kafkas Universitesi Veteriner Fakultesi Dergisi, 19, 861-867.

http://vetdergikafkas.org https://doi.org/10.9775/kvfd.2013.8988

[50] Assefa, S., Melesse, A. and Banerjee, S. (2019) Egg Production and Egg Quality Traits of Local and Exotic Chicken Breeds Reared in Two Agroecologies under Traditional Management System. Research Journal of Food and Nutrition, 3, 11-17.

[51] Nwagu, B.I., lyiola-Tunji, A.O., Akut, R. and Uhwesi, Y.A. (2010) Phenotypic Correlation of Egg Quality Traits of Anak and Hubbard Broiler Grandparent Stock in the Northern Guinea Savannah. Proceedings of the Nigerian Society for Animal 
Production Conference, Ibadan, 64-68.

[52] Apuno, A.A., Mbap, S.I. and Ibrahim, T. (2011) Characterization of Local Chickens (Gallus gallus domesticus) in Shelleng and Songs Local Government Areas of Adamawa State, Nigeria. Agricultural Boillogy, Journal of North America, 2, 6-14. https://doi.org/10.5251/abjna.2011.2.1.6.14

[53] Obike, O.M. and Azu, K.E. (2012) Phenotypic Correlations among Body Weight, External and Internalegg Quality Traits of Pearl and Black Strains of Guinea Fowl in a Humid Tropical Environment. Journal of Animal Sciences Advanced, 2, 857-864.

[54] Summer, J.D. and Leeson, S. (1993) Influence of Pre-Lay Treatment and Dietary Protein Level on the Reproductive Performance of White Leghorn Hens. Journal of Poultry Science, 72, 1705-1713. https://doi.org/10.3382/ps.0721705

[55] Obike, O.M., Oke, U.K. and Azu, K.E. (2011) Comparison of Egg Production Performance and Egg Quality Traits of Pearl and Black Strains of Guinea Fowl in a Humid Rain-Forest Zone of Nigeria. International Journal of Poultry Science, 10, 547-551. https://doi.org/10.3923/ijps.2011.547.551

[56] Sinha, B., Mandal, K., Kumari, R. and Kumari, T. (2018) Estimate and Effect of Breeds on Egg Quality Traits of Poultry: A Review. International Journal of Livestock Research, 8, 8-21. https://doi.org/10.5455/ijlr.20170812102444

[57] Marinko, V., Jotanovic, S. and Savic, Đ. (2018) Certain Egg Quality Parameters of Gray Guinea Fowl in Extensive Rearing. Biotechnology in Animal Husbandry, 34, 207-215. https://doi.org/10.2298/BAH1802207V

[58] Nickolova, M. (2009) Investigation on Some Main Reproductive Characteristics of Guinea Fowls (Numida meleagris). Agricultural Sciences, 1, 55-59. (In Bulgarian) https://doi.org/10.22620/agrisci.2009.02.009

[59] Fursido, T. (1986) Studies on the Meat Production Potentials of Some Local Strains of Chickens in Ethiopia. PhD Thesis, the University Giessen, Gießen, 123-126.

[60] Tesfaye, E., Alebachew, W. and Tamir, B. (2018) Performance of Koekoek Chicken Fed with Different Levels of Moringa oleifera Leaf Meal. Journal of Animal Science Research, 2. https://doi.org/10.16966/2576-6457.115

[61] Panheleux, M., Kalin, O., Gautron, J. and Nys, Y. (2010) Features of Eggshell Formation in Guinea Fowl: Kinetics of Shell Deposition, Uterine Protein Secretion and Uterine Histology. Journal of British Poultry Science, 40, 632-643. https://doi.org/10.1080/00071669987025

[62] Harms, R.H. and Hussein, S.M. (1993) Variation in Yolk: Albumen Ratio in Hen Eggs from Commercial Flock. Journal of Applied Poultry Research, 2, 166-170. https://doi.org/10.1093/japr/2.2.166

[63] Kgwatalala, P.M., Bolebano, L. and Nsoso, S.J. (2013) Egg Quality Characteristics of Different Varieties of Domestic Helmented Guinea Fowl (Numida meleagris). International Journal of Poultry Science, 12, 245-250. https://doi.org/10.3923/ijps.2013.245.250

[64] Melesse, A., Maak, S., Schmidt, R. and Lengerken, V.G. (2011) Effect of Long-Term Heat Stress on Some Performance Traits and Plasma Enzyme Activities in Naked-Neck Chickens and Their F1 Crosses with Commercial Layer Breeds. Livestock Science, 141, 227-231. https://doi.org/10.1016/j.livsci.2011.06.007

[65] Assan, N. (2015) Genotype and Sex Influencing Dressing Percentage, Carcass Parameters and Meat Quality Properties in Indigenous Chickens. Scientific Journal of Biological Science, 4, 43-52.

[66] USDA (United States Department of Agricultural) (2000) Egg Grading Manual. https://www.ams.usda.gov/publications/content/egg-grading-manual 
[67] Tadesse, D., Singh, H., Mengistu, A., Esatu, W. and Dessie, T. (2015) Study on Productive Performances and Egg Quality Traits of Exotic Chickens under Village Production System in East Shewa, Ethiopia. African Journal of Agricultural Research, 8, 1123-1128. https://doi.org/10.5897/AJAR2013.6987

[68] Suk, Y.O. and Park, C. (2001) Effect of Breed and Age of Hens on the Yolk to Albumen Ratio in Two Different Genetic Stocks. Poultry Science, 80, 855-858. https://doi.org/10.1093/ps/80.7.855

[69] Van Marle-Köster, E., Hefer, C.A., Nel, L.H. and Groenen, M.A.M. (2009) Genetic Diversity and Population Structure of Locally Adapted South African Chicken Lines: Implications for Conservation. South African Journal of Animal Science, 38, 271-281. 